\title{
Activation of antioxidant defences of human mammary epithelial cells under leptin depend on neoplastic state
}

Sinda Mahbouli', Jérémie Talvas', Audrey der Vartanian', Sophie Ortega', Stéphanie Rougé Marie-Paule Vasson ${ }^{1,2}$ and Adrien Rossary ${ }^{1 *}$ (i)

\begin{abstract}
Background: Obesity is associated with oxidative stress, a major factor in carcinogenesis, and with high leptin concentration. The aim of this study was to determine the effects of leptin on the antioxidant response in three human mammary epithelial cells each presenting a different neoplastic status: healthy human mammary epithelial cells (HMEC), oestrogen-receptor positive MCF-7 cells and triple-negative MDA-MB-231 cells.

Methods: This in vitro kinetic study characterized the cell antioxidant response after 1, 6 and $24 \mathrm{~h}$ in the presence of leptin (10 or $100 \mathrm{ng} / \mathrm{ml}$ ).The antioxidant response was defined in terms of cell glutathione content, gene expression and catalytic activity of antioxidant enzymes (i.e. glutathione peroxidase 1 (Gpx1), glutathione reductase (GR), glutathione $\mathrm{S}$ transferase (GST), heme-oxygenase 1 (HO-1) and cyclooxygenase-2 (COX-2)). Oxidative stress occurrence was assessed by lipid hydro peroxide (HPLIP) and isoprostane concentrations in culture media at $24 \mathrm{~h}$.

Results: At both concentrations used, leptin induced ROS production in all cell models, contributing to various antioxidant responses linked to neoplastic cell status. HMEC developed a highly inducible antioxidant response based on antioxidant enzyme activation and an increase in cell GSH content at $10 \mathrm{ng} / \mathrm{ml}$ of leptin. However, at 100 $\mathrm{ng} / \mathrm{ml}$ of leptin, activation of antioxidant response was lower. Conversely, in tumour cells, MCF-7 and MDA-MB-231, leptin did not induce an efficient antioxidant response, at either concentration, resulting in an increase of lipid peroxidation products.
\end{abstract}

Conclusions: Leptin can modulate the oxidative status of mammary epithelial cells differently according to their neoplastic state. These novel results shed light on oxidative status changes in mammary cells in the presence of leptin.

Keywords: Adipokines, Oxidative stress, Breast carcinogenesis, Cyclooxygenase, Glutathione, Heme-oxygenase, Lipid peroxidation

\section{Background}

In obesity, accumulation of fat [1] is related to metabolic disorders [2], which are a risk factor for chronic diseases such as cancers [3]. Leptin, an adipokine upregulated during obesity, has been widely studied in carcinogenesis because of its many signalling pathways [4] involved in critical steps of pathogenesis such as cell proliferation [5, 6], inflammatory response [7] and modulation of the tumour environment [8]. Leptin is also known to reduce

\footnotetext{
* Correspondence: adrien.rossary@uca.fr

'Université Clermont Auvergne, INRA, UMR 1019, Unité de Nutrition

Humaine, CRNH-Auvergne, F-63000 Clermont-Ferrand, France

Full list of author information is available at the end of the article
}

the efficacy of antioestrogen therapy [9]. Studies have clearly identified obesity, owing to the humoral secretions it entails, as a major risk factor in post-menopausal breast cancer [10]. However, very few studies have assessed the ability of these secretions to change cell metabolism with regard to oxidative status, especially that of primary healthy cells [11]. Oxidative stress is known to be involved in carcinogenesis [12], to modulate many cell signalling pathways [13] and to be linked to inflammation [14], but data are sparse on how leptin affects oxidative stress in breast cancer [15].

Because oxidative stress can be induced by obesity [16] and has a known role in carcinogenesis [12] we

(c) The Author(s). 2018 Open Access This article is distributed under the terms of the Creative Commons Attribution 4.0 International License (http://creativecommons.org/licenses/by/4.0/), which permits unrestricted use, distribution, and 
set out to study the oxidative status of different mammary epithelial cells. Our team's previous work showed that leptin induced an inflammatory response in breast cancer in mice [17], and a different proliferative effect on neoplastic cells $[5,18]$. We also showed that cytotoxicity of Natural Killer cells declined under leptin in obesity condition [19]. We hypothesized that between healthy and neoplastic cells, the different integration of the leptin signalling is due not only to their neoplastic status [20], but also to their oxidative status [21]. Regarding literature, plasma leptin concentrations were defined around 10 to $30 \mathrm{ng} / \mathrm{ml}$ and 50 to $150 \mathrm{ng} / \mathrm{ml}$ respectively for a lean and an obese adult woman [22]. Thus, we chose leptin doses at $10 \mathrm{ng} / \mathrm{mL}$ for physiological and $100 \mathrm{ng} / \mathrm{mL}$ for obese conditions, which are also relevant to tissue concentrations [8]. The aim of this work was thus to determine whether leptin at two concentrations would modulate oxidative status during a short 24-h time window, in terms of both oxidative production and antioxidant responses and subsequently would lead to an oxidative stress. Using healthy mammary epithelial cells (HMEC), and neoplastic MCF-7 and MDA-MB-231 cells, respectively known to be oestrogen-receptor-positive $(E R+)$ and triple-negative metastatic cells, we characterized the cell antioxidant response. Among the antioxidant systems, we focused on the GSH metabolism, as it is the major cell antioxidant pathway. We investigated the mRNA expression and catalytic activity of the following antioxidant enzymes. Glutathione reductase (GR) reduces oxidized glutathione disulphide back to the reduced form GSH. Glutathione peroxidase 1 (GPx1) catalyses the reduction of harmful lipid peroxides in presence of GSH and protects the lipid membranes against oxidative damage [23]. Glutathione S Trans ferases (GSTs) are involved in cell detoxification by catalysing the conjugation of GSH to lipophilic compounds thereby increasing their solubility and excretion from the cell [24] and are involved in drug detoxifying by neoplastic cells [25]. Finally, heme oxygenase 1 (HO-1), a key regulator of cell redox homeostasis, becomes constitutive in neoplastic cells [26] and is strongly induced [26] to protect cells against toxic metabolites, oxidative stress and injuries [27-29]. In parallel, to assess the oxidative stress, intracellular protein thiol content and extracellular lipid peroxidation products such as lipid hydro peroxides (HPLIP) and isoprostanes (8-iso-PGF2 $\alpha$ ) were measured [30, 31]. Glutathione (GSH) and the redox state of protein thiols may overlap in the activation and regulation of many pathways such as kinases and transcription factors, besides compartmentalized functions $[32,33]$. Lastly, the mRNA expression and catalytic activity of cyclooxygenase 2 (COX-2) were determined, as this enzyme is a well-known prognostic factor in early breast cancer [34] and makes a link between oxidative stress and inflammation [31]. Altogether, these markers characterize the antioxidant response to oxidative stress: high GSH content or antioxidant enzyme activities, induced by oxidative stress, define a protective state. Conversely, low GSH content or antioxidant enzyme activities, associated with a loss of inducibility to oxidative stress, define an aggressive state [24,35].

\section{Materials and methods}

\section{Cell culture}

Healthy human mammary epithelial cells (HMEC, Caucasian woman aged 55 years, oestrogen receptor positive (ER + ), progesterone receptor (PR) positive, human epidermal growth factor receptor 2 (HER2) positive; Lonza, Basel, Switzerland) grew in complete MEBM medium, supplemented with hydrocortisone $(0.5 \mu \mathrm{g} / \mathrm{ml})$, epithelial growth factor $(10 \mathrm{ng} / \mathrm{ml})$, insulin $(5 \mu \mathrm{g} / \mathrm{ml})$, gentamicin $(50 \mu \mathrm{g} / \mathrm{ml})$ / amphotericin-B (50 ng/ml) and bovine pituitary extract $(0.4 \%)$ as recommended by the manufacturer (Lonza). Neoplastic human mammary epithelial cells were MCF-7 (ER+, PR+ and HER2+ cells from metastatic breast tumour of Caucasian woman aged 69 years), and MDAMB-231 (ER-, PR-, HER2-, triple-negative cells from metastatic breast tumour of Caucasian woman aged 51 years). Neoplastic cells (ATCC, Molsheim, France) grew in RPMI 1640 medium (Biowest, Nuaillé, France) containing 10\% foetal calf serum, ${ }_{\mathrm{L}}$-glutamine $(2 \mathrm{mM})$, penicillin (50 units/ $\mathrm{ml})$ and streptomycin $(50 \mu \mathrm{g} / \mathrm{ml})$ (Sigma-Aldrich, SaintQuentin-Fallavier, France). Cultures were at $37^{\circ} \mathrm{C}$ in a humidified atmosphere with $5 \% \mathrm{CO} 2$.

\section{Treatment with leptin}

Mammary epithelial cells (HMEC, MCF7 and MDAMB-231), synchronized in serum free medium for $24 \mathrm{~h}$ before initiation of leptin treatment, grew for $0,1,6$ or $24 \mathrm{~h}$ in their media either with or without recombinant human leptin (R\&D, Abingdon, United Kingdom) at physiological $(10 \mathrm{ng} / \mathrm{ml})$ or obese $(100 \mathrm{ng} / \mathrm{ml})$ concentrations.

Cells were harvested after trypsinization and three phosphate buffer saline washes. Total cell lysates were obtained by two successive thawing-freezing cycles in TrisHCl $25 \mathrm{mM}$ buffer pH 7.4 containing Tween 20 0.1\% (Sigma-Aldrich, Saint-Quentin-Fallavier, France), with 15 -s periods in an ultra-sound bath, and then stored at $-80^{\circ} \mathrm{C}$ until analysis.

Proteins were quantified by the bicinchonic acid method (Interchim, Montluçon, France) using a standard curve with a bovine serum albumin solution $(2 \mathrm{~g} / \mathrm{l})$, according to the manufacturer's instructions. 
RNA isolation and reverse transcription

After treatment with leptin, total RNA were isolated from the epithelial cells by Trizol $^{\circledR}$ reagent (Invitrogen, Saint-Aubin, France) according to the manufacturer's protocol and quantified using a NanoDrop spectrophotometer (Nanodrop ${ }^{\circledR}$ 2000, Thermo Scientific, Waltham, MA). Reverse transcription was performed in a thermocycler (Mastercycler ${ }^{\circledR}$ gradient, Eppendorf, Montesson, France), on $1 \mu \mathrm{g}$ of total RNA for each condition using a high-capacity cDNA reverse transcription kit (Applied Biosystems, Saint Aubin, France) with random hexamer pdN6 primers.

\section{Quantitative real-time PCR (qPCR)}

qPCR was performed using $\mathrm{SYBR}^{\circ}$ Green reagents according to the manufacturer's instructions on a StepOne system (Applied Biosystems, Saint-Aubin, France). Each condition ran in triplicate. Relative quantification was obtained by the comparative CT method, based on the formula $2^{-\Delta \Delta C T}$. Expression levels were normalized to the housekeeping gene ( $\beta$ actin) for each time point, and expressed as fold change from the basal expression level corresponding to untreated cells at time 0 . Table 1 reports sequences and fragment sizes of the human-specific primers used for analysis.

\section{Quantification of reactive oxygen species (ROS) production}

After synchronization, human mammary epithelial cells, plated at a density of 22,500 cells $/ \mathrm{cm}^{2}$ in a 96 -well plate, incubated in the appropriate growth medium with dihydroethidine $(2 \mu \mathrm{M})$ in the dark for $30 \mathrm{~min}$ at $37^{\circ} \mathrm{C}$. Experimentation started by the addition of leptin $(10 \mathrm{ng} / \mathrm{ml}$ or $100 \mathrm{ng} / \mathrm{ml}$ ) or medium (for control conditions). ROS production fluorescence was measured every $10 \mathrm{~min}$ over a 120-min window, using a microplate reader (Fluoroscan Ascent Microplate Fluorometer ${ }^{\bullet}$, Thermo Scientific, Waltham, MA), set on an excitation wavelength of $485 \mathrm{~nm}$ and an emission wavelength of $520 \mathrm{~nm}$. Fluorescence was corrected for background for each well.

\section{Enzyme activities \\ Heme oxygenase}

Heme oxygenase (HO-1) activity was measured by following the degradation of heme in biliverdin using the method of Shih and Yang modified [36]. Hemin $(10 \mu \mathrm{M})$ transformation by cell lysate was determined in the presence of the buffer reagent $(100 \mathrm{mM}$ TrisHCl, $2 \mathrm{mM}$ EDTA, $2 \mathrm{mM} \mathrm{MgCl}$, 0.5\% Tween 20, $2 \mathrm{mM} \mathrm{NADPH,}$ pH 7.4) (Sigma-Aldrich, Saint-Quentin-Fallavier, France) by kinetic measurement at $405 \mathrm{~nm}$ and $37^{\circ} \mathrm{C}$, in a microplate spectrophotometer reader (Multiskan FC, Thermo Scientific, Waltham, MA). HO-1 activity was in $\mathrm{IU} / \mathrm{g}$ of proteins using an extinction coefficient of $5.8410^{4} \mathrm{~cm}^{-1}$ $\mathrm{M}^{-1}$ for hemin.

\section{Glutathione reductase}

Glutathione reductase (GR) activity was determined as described elsewhere [37]. The cell lysate was incubated with buffer reagent (100 mM Tris- $\mathrm{HCl}, 1 \mathrm{mM}$ EDTA, $0.16 \mathrm{mM}$ $\mathrm{NADPH}$ and $4.6 \mathrm{mM}$ oxidized glutathione (GSSG), $\mathrm{pH}$ 7.4) (Sigma-Aldrich, Saint-Quentin-Fallavier, France). Kinetic NADPH oxidation was followed at $340 \mathrm{~nm}$ and $37^{\circ} \mathrm{C}$ for $3 \mathrm{~min}$ in a microplate spectrophotometer reader. GR activity, normalized to the protein content, was in IU/g.

\section{Glutathione peroxidase}

Glutathione peroxidase (GPx) activity resulted in the oxidation of GSH in the presence of tert-butylhydroperoxide. Secondarily GR recycled GSSG in the presence of NADPH [38]. The cell lysate was incubated with buffer reagent (100 mM Tris- $\mathrm{HCl}, 1 \mathrm{mM}$ EDTA, 22 $\mathrm{mM}$ tert-butyl-hydroperoxide, $5 \mathrm{mM}$ GSH, $0.1 \mathrm{IU} / \mathrm{ml}$ GR, 2 mM NADPH, pH 7.4) (Sigma-Aldrich, Saint-

Table 1 Summary of PCR primers

\begin{tabular}{|c|c|c|c|c|}
\hline Gene name & Accession number & Primer sequences & & Amplicon length \\
\hline \multirow[t]{2}{*}{$\mathrm{HO}-1$} & BC_001491 & 5' ACA-GTT-GCT-GTA-GGG-CTT-TA 3' & Foward & $247 \mathrm{bp}$ \\
\hline & & 5' CTC-TGA-AGT-TTA-GGC-CAT-TG 3' & Reverse & \\
\hline \multirow[t]{2}{*}{ GPX1 } & NP_002076 & 5' GCA-CCC-TCT-CTT-CGC-CTT-C 3' & Foward & $222 \mathrm{bp}$ \\
\hline & & 5' TCA-GGC-TCG-ATG-TCA-ATG-GTC 3' & Reverse & \\
\hline \multirow[t]{2}{*}{ GR } & BC_069244 & 5' GTC-AGT-GGG-AAA-AAG-TAC-AC 3' & Foward & $244 \mathrm{bp}$ \\
\hline & & 5' GTA-CCT-TAT-CAT-GCC-GTA-TC 3' & Reverse & \\
\hline \multirow[t]{2}{*}{ COX-2 } & NM_000963 & 5'-TCT-CCT-TGA-AAG-GAC-TTA-TG - $3^{\prime}$ & Foward & $198 \mathrm{bp}$ \\
\hline & & 5'-CAT-TGA-TGG-TGA-CTG-TTT-TA -3' & Reverse & \\
\hline \multirow[t]{2}{*}{$\beta$ actin } & NM_001101 & 5' TCG-TGC-GTG-ACA-TTA-AGG-AG 3' & Foward & $262 \mathrm{bp}$ \\
\hline & & 5' AGC-ACT-GTG-TTG-GCG-TAC-AG 3' & Reverse & \\
\hline
\end{tabular}


Quentin-Fallavier, France). Kinetic NADPH oxidation due to GSH recycling was followed at $340 \mathrm{~nm}$ and $37^{\circ} \mathrm{C}$, in a microplate spectrophotometer reader. GPx activity, normalized to the protein content, was in IU/g.

\section{Glutathione S-transferase}

Glutathione S-transferase (GST) activity was quantified as previously described [37] using the conjugation reaction of GSH with artificial substrate 1-chloro-2,4-dinitrobenzene. The cell lysate incubated with buffer reagent $(50 \mathrm{mM}$ HEPES, $5 \mathrm{mM}$ GSH, $1 \mathrm{mM}$ 1-chloro-2,4-dinitrobenzene, pH 7.4) (Sigma-Aldrich, Saint-Quentin-Fallavier, France). The kinetic 1-chloro-2,4-dinitrobenzene-glutathionylation was followed at $340 \mathrm{~nm}$ and $37^{\circ} \mathrm{C}$, in a microplate spectrophotometer reader. GST activity, normalized to the protein content, was in $\mathrm{IU} / \mathrm{g}$.

\section{Cyclo-oxygenase-2}

Cyclo-oxygenase-2 (COX-2) activity was measured using a COX measurement kit from Cayman chemical (Cayman Chemical Company, Ann Arbor, MI). The 24 $\mathrm{h}$ time-point cell lysates incubated according to the manufacturer's instructions. Kinetic measurement was performed at $590 \mathrm{~nm}$ and $37^{\circ} \mathrm{C}$, in a microplate spectrophotometer reader. COX-2 activity, normalized to the protein content, was in $\mathrm{IU} / \mathrm{g}$.

\section{Total glutathione}

Total glutathione (GSH) content was determined by the method of Cereser et al. [39]. Briefly, dithiothreitol reduced cell lysate for $10 \mathrm{~min}$ at room temperature and glutathione ethyl ester was added as an internal standard. After protein precipitation, the supernatant was derivatized by adding ortho-phthal-aldehyde (OPA) (Sigma-Aldrich, Saint-Quentin-Fallavier, France). The HPLC separation of GSH-OPA adducts used a UP3 HDO C-18 reversed-phase silica column $(150 \times 3.60 \mathrm{~mm}$, particle size $3 \mu \mathrm{m}$ ) from Phenomenex (Interchim, Montluçon, France) maintained at $37^{\circ} \mathrm{C}$ followed by fluorimetric detection at $420 \mathrm{~nm}$ after excitation at $340 \mathrm{~nm}$ (Summit HPLC system, Dionex SA, Courtaboeuf, France). Derivatives eluted using a $10-50 \%$ acetonitrile gradient in a $25 \mathrm{mM}$ phosphate buffer at $\mathrm{pH} 6$ for $5 \mathrm{~min}$. The flow rate was 0.25 $\mathrm{ml} / \mathrm{min}$ for an elution run of $20 \mathrm{~min}$. Chromatograms were integrated using Chromeleon software from Dionex (Version 6.80, Dionex SA, Courtaboeuf, France). GSH content, calculated using a standard curve plotted under the same conditions, was expressed in $\mu \mathrm{mol} / \mathrm{g}$ of protein.

\section{Protein thiols}

Protein thiols were assayed using the method described by Himmelfarb et al. [40]. Free thiol groups oxidized by dithiobis-2-nitrobenzoic acid (Sigma-Aldrich, SaintQuentin-Fallavier, France) were measured at $405 \mathrm{~nm}$ on a microplate spectrophotometer reader. The cell lysate free thiol concentration was expressed as a ratio to protein content in $\mu \mathrm{mol} / \mathrm{g}$.

\section{Lipid peroxidation Lipid hydro peroxides}

Lipid hydro peroxide (HPLIP) quantification in $24 \mathrm{~h}$ time-point culture medium was obtained using the method described by Arab et al. [41]. Culture media were treated by buffer reagent $\left(40 \mathrm{mM} \mathrm{H}_{2} \mathrm{SO}_{4}, 20 \mathrm{mM}\right.$

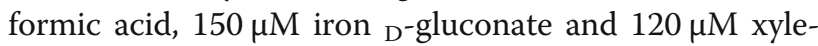
nol orange in glycerol) (Sigma-Aldrich, Saint-QuentinFallavier, France). A standard curve was obtained using a tert-butyl-hydroperoxide solution. Measurements were made at $570 \mathrm{~nm}$ on a microplate spectrophotometer reader. The HPLIP concentration was in $\mu \mathrm{mol} / \mathrm{l}$.

\section{Isoprostanes}

Isoprostane (8-iso-PGF $2 \alpha$ ) quantification in $24 \mathrm{~h}$ timepoint culture medium was obtained using the STAT-8isoprostane EIA measurement kit (Cayman Chemical Company, Ann Arbor, MI). Measurements were made according to the manufacturer's instructions at $405 \mathrm{~nm}$ on a microplate spectrophotometer reader. The 8-isoPGF $2 \alpha$ concentration was in $\mathrm{ng} / \mathrm{l}$.

\section{Statistical analysis}

Each experiment was performed in triplicate and the average value treated as a single data point. Statistical analyses were performed using GraphPad Prism5 (GraphPad Software, Inc., La Jolla, CA). Data are expressed as means \pm standard deviation. Between-group comparisons were performed by one- or two-way ANOVA as appropriate, followed by a Kruskal-Wallis or Bonferroni multiple comparison test. Level of significance was set at 0.05 . Significances are indicated by different subscript letters or flagged as ${ }^{*} p<0.05,{ }^{* *} p<0.01$ and ${ }^{* * *} p<0.001$.

\section{Results \\ Neoplastic breast cancer cells exhibit a lower antioxidative status compared to healthy mammary cells}

(Fig. 1)

Oxidative status is a major cell characteristic involved in the response to cell environment changes. The determination of cytosolic ROS production, of glutathione and protein-thiol contents and of antioxidant catalytic activities characterized the oxidative status of our different mammary epithelial cell models under basal condition (i.e. without leptin).

As usually reported, cytosolic ROS production of superoxide anion $\left(\mathrm{O}_{2}{ }^{\circ}\right)$ was higher in neoplastic cells than in healthy primary cells $(p<0.05$, Fig. 1a). Healthy cells also had a higher glutathione content $(168 \pm 31 \mu \mathrm{mol} /$ g) than neoplastic cells $(-73 \%$ in MCF-7 and $-42 \%$ in 


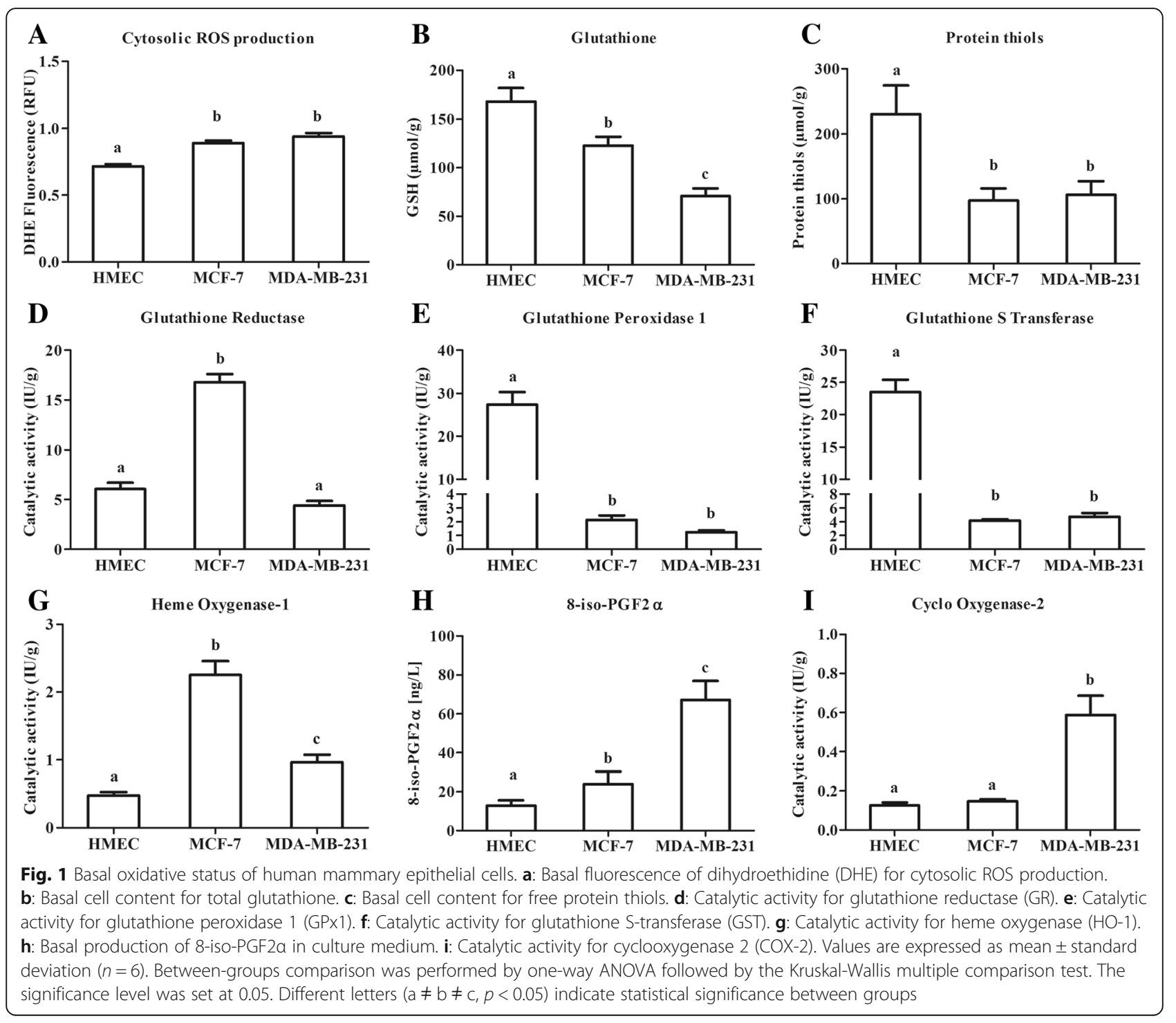

MDA-MB-231 compared with HMEC, $p<0.05$, Fig. 1b). A similar pattern was observed for the protein-thiol content $(p<0.05$, Fig. 1c). This results in a higher redox potential in healthy cells than in neoplastic cells.

GR catalytic activity was 3-fold higher in MCF-7 than in HMEC and MDA-MB-231 (Fig. 1d). HMEC had a 10-fold higher GPx1 catalytic activity, and a 5-fold higher GST catalytic activity than the neoplastic cells (p $<0.05$, Fig. 1e and f). Conversely, neoplastic cells significantly induced HO-1 catalytic activity (4-fold higher in MCF-7 and 2-fold higher in MDA-MB-231 than in HMEC, $p<0.05$, Fig. 1g).

The imbalance between pro- and anti-oxidative systems resulted under basal conditions in an increase in 8 -iso-PGF $2 \alpha$ content in neoplastic cell media $(p<0.05$, Fig. 1h), highlighting a constitutive oxidative stress in these cells even in the absence of leptin. In addition,
MDA-MB-231 cells presented a higher COX-2 catalytic activity than the other cells (Fig. 1i).

Our models presented three different levels of oxidative status. A protective redox defence in the healthy cells characterized by high defence levels. Conversely, triple negative MDA-MB-231 cells showed an aggressive pro-oxidant and inflammatory state. The neoplastic ER+ MCF-7 cells presented an intermediary profile.

Leptin induces an antioxidant response in healthy human mammary epithelial cells but not in the neoplastic cell lines (Figs. 2 and 3)

As healthy and neoplastic cells presented a different basal oxidative status, these cells could integrate the leptin signal differently. We therefore focused on the modulation of oxidative status with 10 and $100 \mathrm{ng} / \mathrm{ml}$ of leptin. The two 


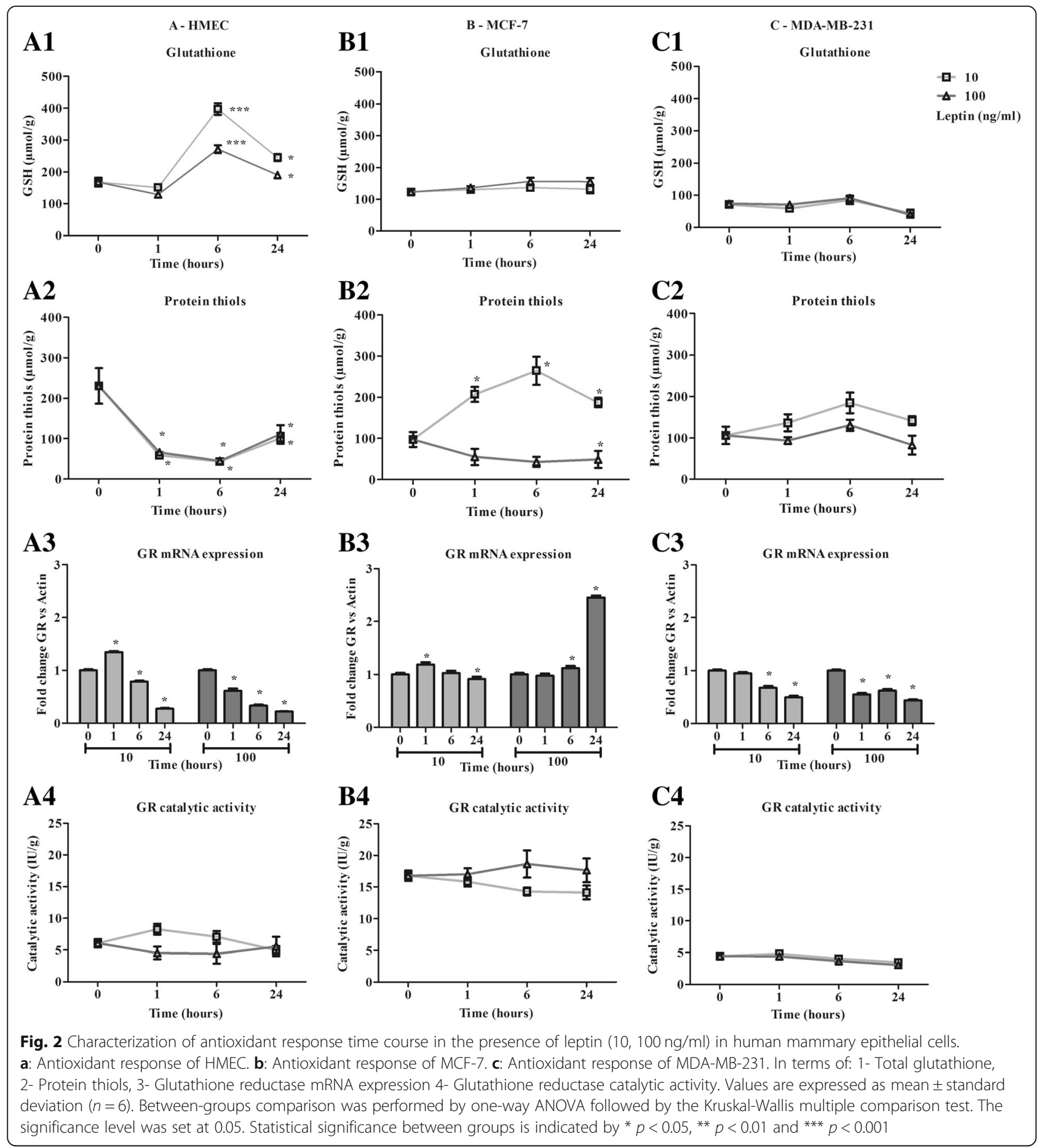

aspects of the oxidative response studied were the non-enzymatic and the enzymatic antioxidant response.

\section{Non enzymatic antioxidant response}

Cell GSH content increased in HMEC at $6 \mathrm{~h}$ from $168 \pm$ $31 \mu \mathrm{mol} / \mathrm{g}$ to $398 \pm 40 \mu \mathrm{mol} / \mathrm{g}$ and $272 \pm 27 \mu \mathrm{mol} / \mathrm{g}$ with 10 and $100 \mathrm{ng} / \mathrm{ml}$ of leptin respectively. GSH content then decreased at $24 \mathrm{~h}$ (Fig. $2 \mathrm{~A} 1$ ). Protein thiols content decreased from $231 \pm 116 \mu \mathrm{mol} / \mathrm{g}$ to around $44 \mu \mathrm{mol} / \mathrm{g}$ at $6 \mathrm{~h}$, and then increased up to $100 \mu \mathrm{mol} / \mathrm{g}$ at $24 \mathrm{~h}$ for both concentrations of leptin (Fig. 2 A2). At both concentrations, leptin induced a change in the redox potential of healthy cells.

GSH content remained stable in MCF-7 and MDAMB-231 with $123 \pm 21 \mu \mathrm{mol} / \mathrm{g}$ and $71 \pm 20 \mu \mathrm{mol} / \mathrm{g}$ 


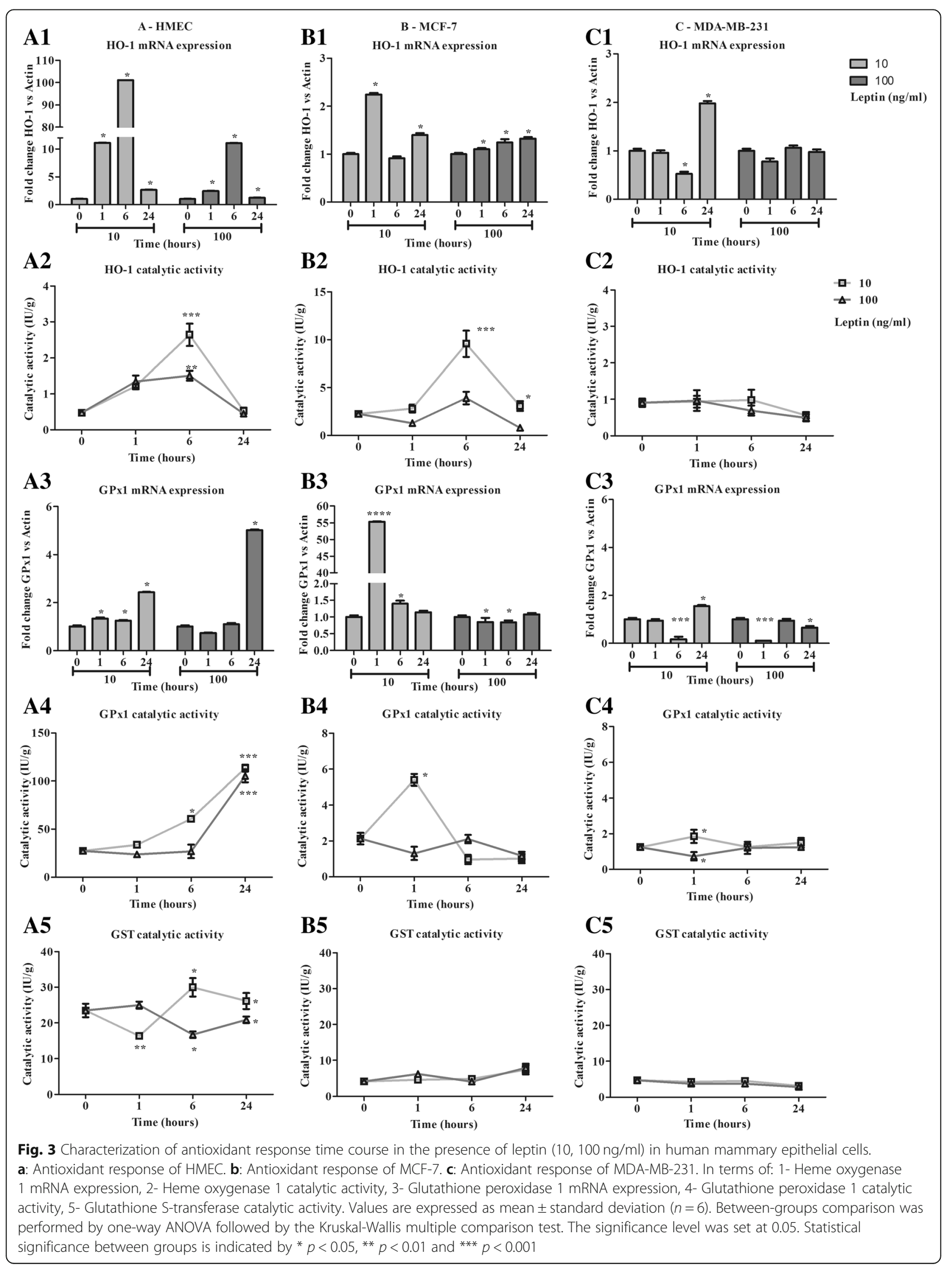


respectively (Figs. $2 \mathrm{~B} 1$ and $\mathrm{C} 1$ ) at both leptin concentrations used. For $10 \mathrm{ng} / \mathrm{ml}$ of leptin, protein thiols content increased from $97 \pm 69 \mu \mathrm{mol} / \mathrm{g}$ to $187 \pm 17 \mu \mathrm{mol} / \mathrm{g}$ at $24 \mathrm{~h}$, whereas a slight decrease was observed with $100 \mathrm{ng} / \mathrm{ml}$ of leptin (Fig. 2 B2) in MCF-7. In MDA-MB-231, no significant effect on protein thiol content was observed (Fig. 2 C2). Taken together, leptin seemed to have a weak effect on redox potential in any of the neoplastic cell models.

\section{Enzymatic antioxidant response}

At both leptin concentrations, the expression of GR decreased steadily from $1 \mathrm{~h}$ to $24 \mathrm{~h}$ with no modification of the catalytic activity, which remained stable in HMEC (Fig. 2 A3). In MCF-7, GR expression remained quite stable until $24 \mathrm{~h}$ except for a 2.45 -fold increase with $100 \mathrm{ng} / \mathrm{ml}$ of leptin (Fig. 2 B3, $p<0.05$ ). However, GR catalytic activity remained stable during the time course and was 3-fold greater than in the other cell models (Fig. 2 B4). In MDA-MB-231, GR expression slightly decreased, and its lowest catalytic activity remained stable (Fig. $2 \mathrm{C} 3$ and $\mathrm{C} 4$ ).

The time course of $\mathrm{HO}-1$ expression in HMEC showed a very marked increase at $1 \mathrm{~h}$ and $6 \mathrm{~h}$ followed by a decrease at $24 \mathrm{~h}$ characterized by a higher level for $10 \mathrm{ng} / \mathrm{ml}$ than for $100 \mathrm{ng} / \mathrm{ml}$ of leptin $(p<0.05$, Fig. 3 A1). As expected, catalytic activity increased from $1 \mathrm{~h}$ to $6 \mathrm{~h}(p<0.05$, Fig. 3 A2). In neoplastic cells, mRNA expression increased at a low level (MCF-7: $2.2 \pm 0.1$-fold expression at $1 \mathrm{~h}$; MDA-MB-231: $2.0 \pm 0.1$-fold expression at 24h, Figs. $3 \mathrm{~B} 1$ and $\mathrm{C} 1$ ), resulting in MCF7 in an increase in catalytic activity at $6 \mathrm{~h}$ to $9.6 \pm 3.1 \mathrm{IU} / \mathrm{g}$ for $10 \mathrm{ng} / \mathrm{ml}$ of leptin (Fig. 3 B2). In MDA-MB-231, activity remained stable at $1.0 \pm 0.4 \mathrm{IU} / \mathrm{g}$ from 0 to $6 \mathrm{~h}$ then slightly decreased at $24 \mathrm{~h}$ (Fig. $3 \mathrm{C} 2$ ), underscoring the loss of inducibility of this enzyme in the neoplastic cells.

In HMEC, leptin induced an increase in GPx1 expression at $24 \mathrm{~h}$ to $2.4 \pm 0.1$ - and $5.0 \pm 0.1$-fold expression (Fig. 3 A3). That resulted in marked activation of the catalytic activity from $27.3 \pm 2.9 \mathrm{IU} / \mathrm{g}$ to around $110 \mathrm{IU} / \mathrm{g}$ at $24 \mathrm{~h}(\mathrm{p}<0.05$, Fig. $3 \mathrm{~A} 4)$. In neoplastic cells, mRNA expression was induced principally for MCF-7 at $1 \mathrm{~h}$ with $10 \mathrm{ng} / \mathrm{ml}$ of leptin, which resulted in a time-limited increase in catalytic activity (Fig. 3 B4). In MDA-MB231 , a very marked but time-limited decrease in expression was observed at $6 \mathrm{~h}$ at both leptin concentrations, with no effect on catalytic activity (Fig. 3 C4).

A slight increase to $26.1 \pm 2.3 \mathrm{IU} / g$ and a slight decrease to $20.9 \pm 0.9 \mathrm{IU} / \mathrm{g}$ were observed in the GST catalytic activity of HMEC at $24 \mathrm{~h}$ for $10 \mathrm{ng} / \mathrm{ml}$ and $100 \mathrm{ng} / \mathrm{ml}$ of leptin, respectively (Fig. 3 A5), whereas no significant change was observed in neoplastic cells (Fig. 3 B5 and C5).

Leptin induced antioxidant defences in healthy cells, with less efficacy under the greater concentration.
Whereas, leptin resulted in a partial induction of antioxidant defences in neoplastic ER+ cells only at the lower concentration and had no effect on the triple-negative cells.

\section{Leptin results in an inflammatory signalling in the three cell lines and an oxidative stress via lipid peroxidation in neoplastic cells only (Fig. 4)}

Imbalance between pro- and anti-oxidative responses could result in lipid peroxidation related to a proinflammatory status favouring carcinogenesis and tumour growth. Lipid peroxidation products in culture medium and cell COX-2 activity were therefore assayed in our models.

In all cell lines, cytosolic ROS production increased in the presence of leptin $(119,107$ and $125 \%$ of basal production, respectively for HMEC, MCF-7, MDA-MB-231; Fig. 4 a). In response to the ROS production and the antioxidant response (from the activation of GPx1), at $24 \mathrm{~h}$ and at either dose of leptin, in HMEC, no lipid peroxidation was observed, HPLIP and 8-iso PGF $2 \alpha$ contents remaining stable in the culture medium (Fig. 4 $\mathrm{b}$ and c). An overexpression of COX-2 mRNA at $1 \mathrm{~h}$ and $6 \mathrm{~h}$ was observed and resulted in a significant increase in COX-2 activity at $24 \mathrm{~h}$ (Fig. $4 \mathrm{~d}$ and $\mathrm{g}$ ).

Conversely, in neoplastic cells, a 2 -fold increase in HPLIP content was observed (Fig. 4 b). In the same way, 8 -iso-PGF2 $\alpha$ content increased for both concentrations of leptin in the two neoplastic cell lines at a higher level for MDA-MD-231 cells (Fig. 4 c). At both concentrations of leptin, an overexpression of COX-2 mRNA at 1 $\mathrm{h}$ was observed in all cell lines (Fig. $4 \mathrm{~d}$, e and $\mathrm{f}$ ). In MDA-MB-231 the overexpression observed at $1 \mathrm{~h}$ persisted up to $24 \mathrm{~h}$ (Fig. $4 \mathrm{f}$ ). These mRNA expression increases resulted in an increase in COX-2 activity at $24 \mathrm{~h}$, which was greater at the concentration of $100 \mathrm{ng} / \mathrm{ml}$ of leptin in the neoplastic cells (Fig. $4 \mathrm{~g}$ ).

Finally, leptin signalling resulted in a pro-inflammatory environment associated to lipid peroxidation in neoplastic cells, whereas antioxidant defence induction prevented lipid peroxidation of healthy cells.

\section{Discussion}

Several studies have investigated the impact of leptin in carcinogenesis in terms of cell proliferation [5], invasiveness [6], or angiogenesis and cell metabolism [42], but few have focused on the oxidative status of mammary neoplastic cells [43] despite some evidences in healthy cells [44]. In the present study, we compared the effect of leptin on oxidative status in three cell lines representing different neoplastic states, from healthy to metastatic.

On the basal condition, our models presented three different levels of oxidative status, from a protective redox 


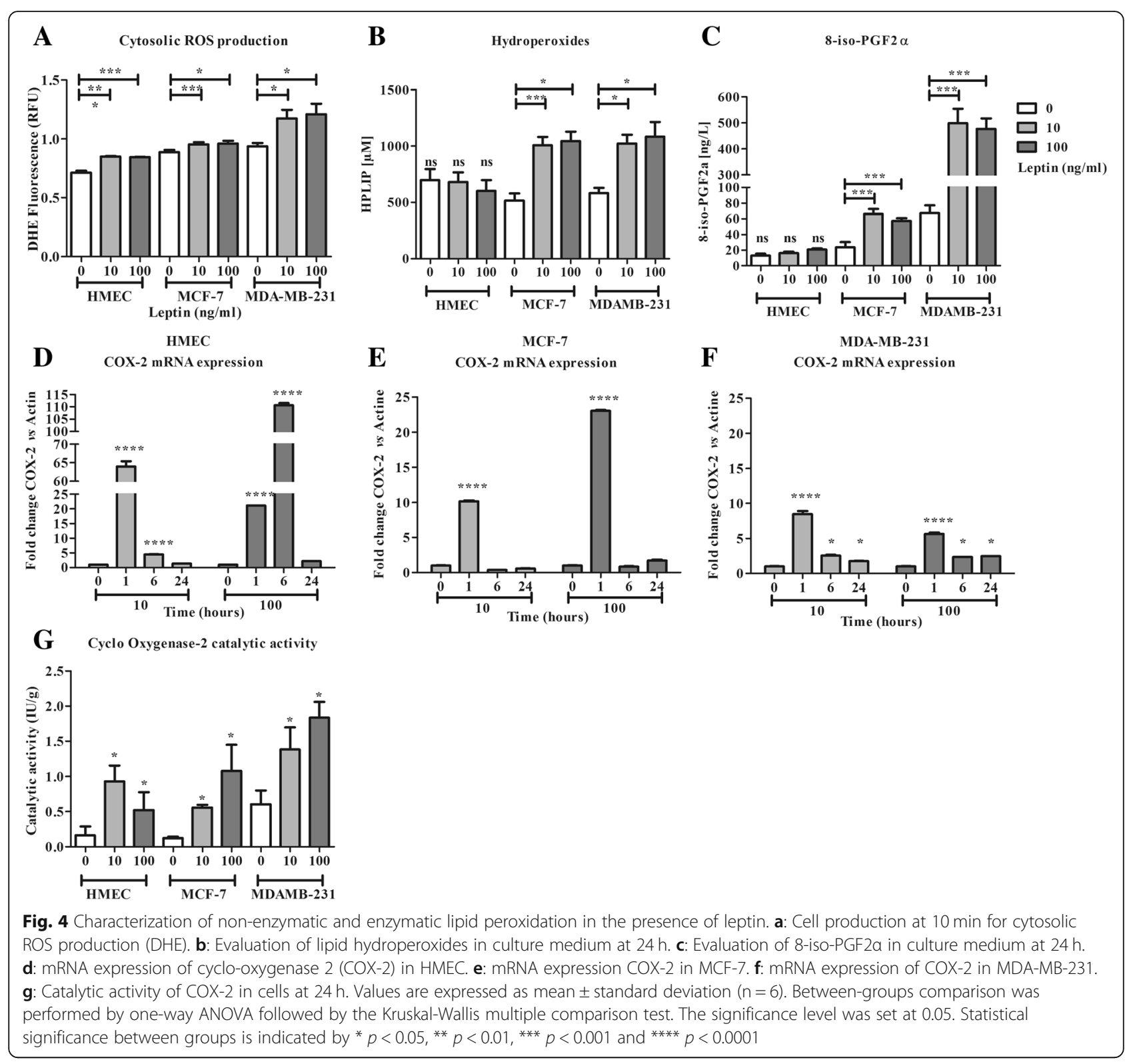

defence in the healthy cells (characterized by higher cell concentrations of glutathione and enhanced GPx and GST catalytic activities) to an aggressive pro-oxidant and inflammatory state in MDA-MB-231 (lower antioxidant defences and higher COX-2 activity) $[45,46]$. The neoplastic MCF-7 cells presented an intermediary profile characterized by high catalytic activities for GR and HO-1 but lower GSH and free protein thiol contents. We also showed that cytosolic ROS production at basal level was higher in neoplastic cells than in healthy mammary cells. Many of our observations are in line with biological characteristics of these cell lines [46, 47]. Mitochondrial ROS production was greater with a very low cytosolic ROS production, consistent with cell metastatic ability [48]. HO-1 lost its induction capacities, and its basal catalytic activity was greater than that of the healthy cells [26]. Nonetheless, this inducible enzyme became constitutive in neoplastic cells owing to a permanent transcription [29, 49] as shown in MCF-7 and MDA-MB-231 cells. The COX-2 expression and catalytic activity was greater in MDA-MB-231 cells than in the other cells [45]. Also, the stress resulting from a greater ROS production and a lower antioxidant defence protection [50], leads to an increase in the pro inflammatory product 8 -iso-PGF2 $\alpha$. These results are in line with the constitutive oxidative stress widely observed in cancer cells $[10,14]$ which promotes tumorigenesis, vascularization and cell growth [51]. 
Many of the leptin signalling pathways, such as STAT3, PI3K-AKT or MAPK, are redox-sensitive and can be modulated by the oxidative status [8]. Oxidative status is a powerful mechanism for the regulation of various aspects of cell metabolism and functions such as stress defences [13], oestrogen receptor activity [52], and cell proliferation or inflammation [53]. GSH and protein thiols may have overlapped effects in the regulation of many signalling pathways through redox state of kinases and transcription factors [32, 33]. In the field of leptin signalling, p53 [54] and STAT3 [21] are regulated by their disulphide oxidative status and glutathionylation [32]. In addition, the PI3K-AKT pathway, one of the canonical leptin pathways [55], can stimulate NF-kb involved in the antioxidant response and cell growth $[50,56]$. In this light, the differences in basal oxidative status between healthy and neoplastic cells could contribute, via the disulphide oxidative status of the signalling pathway, to different responses to leptin [57].

As leptin is able to increase cell ROS production in our cell lines, the antioxidant response was characterized in our cell lines after leptin stimulation.

At both leptin concentrations, HMEC exhibited a strong antioxidant response due to the mRNA overexpression of the major antioxidant enzymes (HO-1, GPx1), which results in an increase in their catalytic activity. Owing to the activation of GPx1, no increase was observed in the pro-inflammatory products of lipid peroxidation such as HPLIP or the non-enzymatic 8 -iso-PGF2 $\alpha$. However, in presence of leptin, a stimulation of both mRNA expression and catalytic activity of COX-2 appeared and conducted to an inflammatory response. In addition, a considerable increase in GSH was observed and the protein thiols were oxidized, which are evidence of an antioxidant defence [57, 58] and of cell adaptation to the environment [59]. However, in presence of $100 \mathrm{ng} / \mathrm{ml}$ of leptin, the antioxidant response was lower in healthy cells. Indeed, there was a lower production of GSH, along with a lack of activation of GST and GR activities and a lower activation of HO-1 and GPx1. The activation of COX2 remained significant. Thus, leptin, known to potentiate cell growth in mammary neoplastic cells [8], seems to be integrated as a threat signal in healthy cells, resulting in the enhancement of the antioxidant defences associated to an inflammatory response. In light of these results, we could hypothesize that in healthy cells, high antioxidative status could favour the NF-kb signalling to enhance antioxidant and inflammatory response, and could inhibit the STAT3 and p53 signalling through glutathionylation. That could explain the huge decrease in protein thiols (Fig. 5a). Moreover, in obese condition, hyperleptinemia favours a pro-inflammatory environment and reduces the antioxidant defence of healthy cells [60]. Thus the healthy tissue could be less efficient in counteracting neoplastic cell growth and anti-tumour signalling [6].

In our conditions, as in previous observations [49, 57, 58, 61, 62], MCF-7 exhibited an incomplete antioxidant response differently modulated by leptin. At the lowest concentration of $10 \mathrm{ng} / \mathrm{ml}$ of leptin, the efficacy of the antioxidant response was related to the induction of HO-1 and GPx1, and the high GR activity (3 times higher than that of the other cells) and to the availability of protein thiols, as shown by the cell content increase. That can reflect a less glutathionylation and/or disulphide level in proteins. However, at $100 \mathrm{ng} / \mathrm{ml}$ of leptin, none of these changes was observed except a late GR mRNA expression increase. This observation could be a transcription regulation to maintain the GR mRNA pool and later the high level of activity, specific in this cell line. Despite an induction of lipid peroxidation defence, leptin signalling resulted in a substantial increase in oxidative damage at both concentrations shown by the majored lipid peroxidation. Moreover, the overexpression of COX-2 was associated with a greater increase in its catalytic activity at both leptin concentrations. This enhanced COX-2 activity and the 8 -iso-PGF2 $\alpha$ production reflect an inflammatory response to leptin favouring neoplastic cell growth [30, 31]. In the case of MCF-7, the intermediate antioxidative status could result in a less activation of NF- $\mathrm{kb}$ signalling, lighted by the lower antioxidant response, and could activate STAT3 and p53 signalling as suggested by the increased protein thiol content (Fig. 5b). Thus our results confirm the implication of leptin signalling in cell growth as previously described [5], and in pro-inflammatory response in ER+ neoplastic cells (Fig. 5b). These data confirm the poorer prognosis observed in breast cancer due to obesity [7], and highlight the role of leptin in this matter [8, 62].

Finally, whatever the concentration used, leptin did not affect the antioxidant response of the triple-negative MDA-MB-231 cells. At both concentrations, these cells still have an aggressive phenotype with low antioxidative status and constitutive activities of COX-2 and HO-1. Moreover, leptin signalling resulted in no change of glutathione or protein thiol contents. This low antioxidative status associated with majored ROS production could favour inflammatory, growth and survival pathways (Fig. 5c), as previously described by our team [5]. All these observations were consistent with the most aggressive profile of this cell line $[62,63]$ which is reinforced in obesity as shown in clinical observations [47].

\section{Conclusions}

This in vitro study helps to gain a better understanding of the oxidative defence in human mammary epithelial cells in response to leptin signalling depending on cell- 


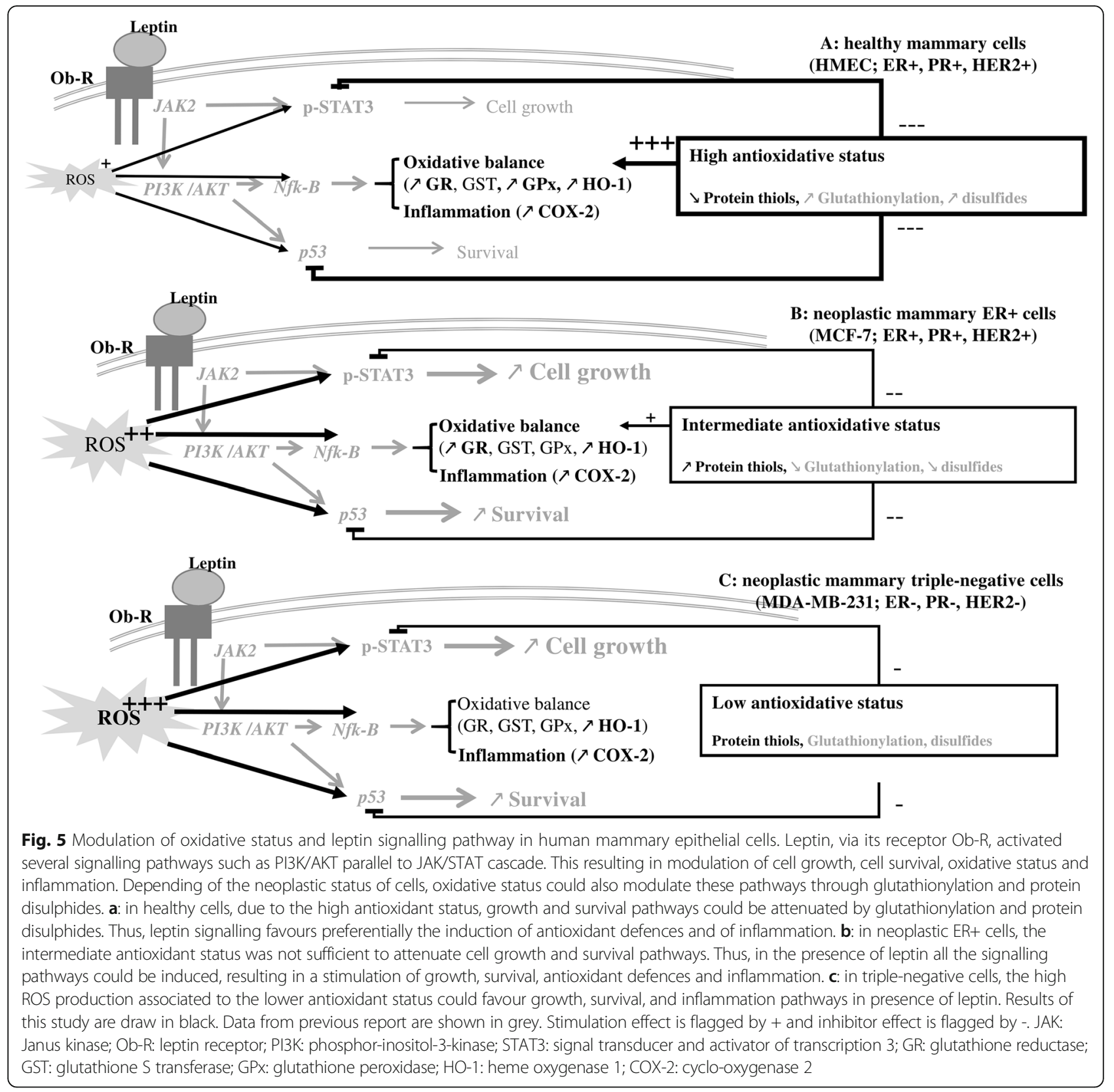

neoplastic status. Healthy cells exhibit an inducible antioxidant response, which is less effective under the hyperleptinemia condition. Conversely, in neoplastic cells, whether ER+ or triple-negative, leptin signalling results in a lack of antioxidant response related to a major oxidative stress and a pro-inflammatory response. These observations support our previous results and indicate that leptin could affect antioxidant status of healthy cells and favour a permissive environment for neoplastic cells. Our novel findings point to a potential link between obesity-related leptin secretion and breast cancer through cell oxidative status, which contributes to the aggravating effect of obesity in breast carcinogenesis. Taken together these data shed new light on the impact of leptin in carcinogenesis and support the utility of modulating leptin signalling pathways and oxidative status in obese patient to obtain health benefits.

\section{Abbreviations}

8-iso-PGF2a: isoprostane; COX-2: Cyclo-oxygenase-2; DHE: Dihydroethidine; ER+: Oestrogen receptor positive; GPX1: Glutathione peroxidase 1;

GR: Glutathione reductase; GSH: Glutathione; GST: Glutathione S-transferase; HER2: Human epidermal growth factor receptor 2; HMEC: Human mammary epithelial cells; HO-1: Heme oxygenase-1; HPLIP: Lipid hydroperoxides; ObR: Leptin receptor; OPA: Ortho-phthal-aldehyde; PR: Progesterone receptor; 
qPCR: Quantitative real-time PCR; RFU: Relative fluorescence unit; ROS: Reactive oxygen species

\section{Acknowledgements}

We thank Samar Basu for his valuable advice and expert knowledge of eicosanoids.

\section{Funding}

This work was supported by a PhD fellowship (Sinda Mahbouli) from the Conseil Régional d'Auvergne and the European research fund (FEDER).

\section{Availability of data and materials}

The datasets used and/or analysed during this study are available from the corresponding author on reasonable request. All data generated or analysed during this study are included in this published article.

\section{Authors' contributions}

SM, AdV and SR carried out the cell culture supervised by M-PV and AR; SM, AdV, SO and SR carried out the laboratory analysis supervised by JT, M-PV and $A R ; S M, M-P V$ and AR conducted the statistical analyses and drafted the manuscript; all the authors contributed to and approved the final version of the manuscript.

\section{Ethics approval and consent to participate}

This study does not involve any active intervention on patients and is performed on commercial cell lines. Therefore, ethics approval and written informed consent are not applicable for this study.

\section{Competing interests}

There is no conflict of interest for any of the authors. The authors alone are responsible for the content and writing of the paper.

\section{Publisher's Note}

Springer Nature remains neutral with regard to jurisdictional claims in published maps and institutional affiliations.

\section{Author details}

'Université Clermont Auvergne, INRA, UMR 1019, Unité de Nutrition Humaine, CRNH-Auvergne, F-63000 Clermont-Ferrand, France. ${ }^{2} \mathrm{CHU}$ Clermont-Ferrand, Centre Jean Perrin, Unité de Nutrition, CLARA, F-63000 Clermont-Ferrand, France.

Received: 1 August 2017 Accepted: 27 November 2018 Published online: 18 December 2018

\section{References}

1. Ceddia RB. Direct metabolic regulation in skeletal muscle and fat tissue by leptin: implications for glucose and fatty acids homeostasis. Int J Obes. 2005;29:1175-83

2. Gregor MF, Hotamisligil GS. Thematic review series: adipocyte biology. Adipocyte stress: the endoplasmic reticulum and metabolic disease. J Lipid Res. 2007:48:1905-14.

3. Vargas-Hernández VM, Vargas-Aguilar V, Moreno-Eutimio MA, AcostaAltamirano G, Tovar-Rodriguez J. Metabolic syndrome in breast cancer. Gland Surg. 2013;2:80-90.

4. Guo S, Liu M, Wang G, Torroella-Kouri M, Gonzalez-Perez RR. Oncogenic role and therapeutic target of leptin signaling in breast cancer and cancer stem cells. Biochim Biophys Acta. 2012;1825:207-22.

5. Dubois V, Jardé T, Delort L, Billard H, Bernard-Gallon D, Berger E, et al. Leptin induces a proliferative response in breast cancer cells but not in normal breast cells. Nutr Cancer. 2014;66:645-55.

6. Barone I, Catalano S, Gelsomino L, Marsico S, Giordano C, Panza S, et al. Leptin mediates tumor-stromal interactions that promote the invasive growth of breast cancer cells. Cancer Res. 2012;72:1416-27.

7. Vona-Davis L, Rose DP. The obesity-inflammation-eicosanoid axis in breast cancer. J Mammary Gland Biol Neoplasia. 2013;18:291-307.

8. Andò $S$, Catalano $S$. The multifactorial role of leptin in driving the breast cancer microenvironment. Nat Rev Endocrinol. 2012;8:263-75.

9. Chen X, Zha X, Chen W, Zhu T, Qiu J, Røe OD, et al. Leptin attenuates the anti-estrogen effect of tamoxifen in breast cancer. Biomed Pharmacother Bioméd Pharmacothérapie. 2013;67:22-30.
10. Macciò A, Madeddu C. Obesity, inflammation, and postmenopausal breast cancer: therapeutic implications. ScientificWorldJournal. 2011;11:2020-36.

11. Martínez-Martínez E, Jurado-López R, Valero-Muñoz M, Bartolomé MV, Ballesteros $\mathrm{S}$, Luaces $\mathrm{M}$, et al. Leptin induces cardiac fibrosis through galectin-3, mTOR and oxidative stress: potential role in obesity. J Hypertens. 2014:32:1104-14.

12. Valko M, Rhodes $\mathrm{CJ}$, Moncol J, Izakovic M, Mazur M. Free radicals, metals and antioxidants in oxidative stress-induced cancer. Chem Biol Interact. 2006;160:1-40.

13. Adler V, Yin Z, Tew KD, Ronai Z. Role of redox potential and reactive oxygen species in stress signaling. Oncogene. 1999;18:6104-11.

14. Sun Y, Huang L, Mackenzie GG, Rigas B. Oxidative stress mediates through apoptosis the anticancer effect of phospho-nonsteroidal anti-inflammatory drugs: implications for the role of oxidative stress in the action of anticancer agents. J Pharmacol Exp Ther. 2011;338:775-83.

15. Badid N, Ahmed FZB, Merzouk H, Belbraouet S, Mokhtari N, Merzouk SA et al. Oxidant/antioxidant status, lipids and hormonal profile in overweight women with breast cancer. Pathol Oncol Res. 2010;16:159-67.

16. Fernández-Sánchez A, Madrigal-Santillán E, Bautista M, Esquivel-Soto J, Morales-González A, Esquivel-Chirino C, et al. Inflammation, oxidative stress, and obesity. Int J Mol Sci. 2011;12:3117-32.

17. Nachat-Kappes R, Pinel A, Combe K, Lamas B, Farges M-C, Rossary A, et al. Effects of enriched environment on COX-2, Leptin and Eicosanoids in a Mouse Model of Breast Cancer. PloS One. 2012;7:e51525.

18. Jardé T, Caldefie-Chézet F, Goncalves-Mendes N, Mishellany F, Buechler C, Penault-Llorca F, et al. Involvement of adiponectin and leptin in breast cancer: clinical and in vitro studies. Endocr Relat Cancer. 2009;16:1197-210.

19. Lamas B, Goncalves-Mendes N, Nachat-Kappes R, Rossary A, Caldefie-Chezet F, Vasson M-P, et al. Leptin modulates dose-dependently the metabolic and cytolytic activities of NK-92 cells. J Cell Physiol. 2013;228:1202-9.

20. Ru P, Steele R, Hsueh EC, Ray RB. Anti-miR-203 upregulates SOCS3 expression in breast Cancer cells and enhances cisplatin Chemosensitivity. Genes Cancer. 2011;2:720-7.

21. Butturini E, Darra E, Chiavegato G, Cellini B, Cozzolino F, Monti M, et al. SGlutathionylation at Cys328 and Cys542 impairs STAT3 phosphorylation. ACS Chem Biol. 2014;9:1885-93.

22. Grossmann ME, Ray A, Nkhata KJ, Malakhov DA, Rogozina OP, Dogan S, et al. Obesity and breast cancer: status of leptin and adiponectin in pathological processes. Cancer Metastasis Rev. 2010;29:641-53.

23. Loschen G, Azzi A, Richter C, Flohé L. Superoxide radicals as precursors of mitochondrial hydrogen peroxide. FEBS Lett. 1974;42:68-72.

24. Matés JM, Pérez-Gómez C, Núñez de Castro I. Antioxidant enzymes and human diseases. Clin Biochemist. 1999:32:595-603.

25. Hayes JD, Flanagan JU, Jowsey IR. Glutathione transferases. Annu Rev Pharmacol Toxicol. 2005;45:51-88.

26. Was H, Dulak J, Jozkowicz A. Heme oxygenase-1 in tumor biology and therapy. Curr Drug Targets. 2010;11:1551-70.

27. Abraham NG, Kappas A. Pharmacological and clinical aspects of Heme oxygenase. Pharmacol Rev. 2008;60:79-127.

28. Balla J, Jacob HS, Balla G, Nath K, Eaton JW, Vercellotti GM. Endothelial-cell heme uptake from heme proteins: induction of sensitization and desensitization to oxidant damage. Proc Natl Acad Sci. 1993;90:9285-9.

29. Lee W-Y, Chen Y-C, Shin C-M, Lin C-M, Cheng C-H, Chen K-C, et al. The induction of heme oxygenase-1 suppresses heat shock protein 90 and the proliferation of human breast cancer cells through its byproduct carbon monoxide. Toxicol Appl Pharmacol. 2014:274:55-62.

30. Basu S. Bioactive eicosanoids: role of prostaglandin $\mathrm{F}(2 \mathrm{a})$ and $\mathrm{F}_{2^{-}}$ isoprostanes in inflammation and oxidative stress related pathology. Mol Cells. 2010;30:383-91.

31. Basu S, Nachat-Kappes R, Caldefie-Chézet F, Vasson M-P. Eicosanoids and adipokines in breast cancer: from molecular mechanisms to clinical considerations. Antioxid Redox Signal. 2013;18:323-60.

32. Ghezzi P. Oxidoreduction of protein thiols in redox regulation. Biochem Soc Trans. 2005;33:1378-81.

33. Lumb RA, Bulleid NJ. Is protein disulfide isomerase a redox-dependent molecular chaperone? EMBO J. 2002;21:6763-70.

34. Kargi A, Uysal M, Bozcuk H, Coskun HS, Savas B, Ozdogan M. The importance of $\mathrm{COX}-2$ expression as prognostic factor in early breast cancer. J BUON. 2013;18:579-84.

35. Basu S. Bioactive eicosanoids: role of prostaglandin $\mathrm{F}(2 \mathrm{a})$ and $\mathrm{F}_{2^{-}}$ isoprostanes in inflammation and oxidative stress related pathology. Mol. Cells. 2010;30:383-91. 
36. Shih R-H, Yang C-M. Induction of heme oxygenase-1 attenuates lipopolysaccharide-induced cyclooxygenase-2 expression in mouse brain endothelial cells. J Neuroinflammation. 2010;7:86.

37. Arab K, Rossary A, Flourié F, Tourneur Y, Steghens J-P. Docosahexaenoic acid enhances the antioxidant response of human fibroblasts by upregulating gamma-glutamyl-cysteinyl ligase and glutathione reductase. $\mathrm{Br}$ J Nutr. 2006;95:18-26.

38. Cheng WH, Ho YS, Ross DA, Han Y, Combs GFJ, Lei XG. Overexpression of cellular glutathione peroxidase does not affect expression of plasma glutathione peroxidase or phospholipid hydroperoxide glutathione peroxidase in mice offered diets adequate or deficient in selenium. J Nutr. 1997;127:675-80.

39. Cereser C, Guichard J, Drai J, Bannier E, Garcia I, Boget S, et al. Quantitation of reduced and total glutathione at the femtomole level by highperformance liquid chromatography with fluorescence detection: application to red blood cells and cultured fibroblasts. J Chromatogr B Biomed Sci App. 2001;752:123-32.

40. Himmelfarb J, McMonagle E, McMenamin E. Plasma protein thiol oxidation and carbonyl formation in chronic renal failure. Kidney Int. 2000;58:2571-8.

41. Arab K, Steghens J-P. Plasma lipid hydroperoxides measurement by an automated xylenol orange method. Anal Biochem. 2004;325:158-63.

42. Nalabolu MR, Palasamudram K, Jamil K. Adiponectin and leptin molecular actions and clinical significance in breast cancer. Int J Hematol Oncol Stem Cell Res. 2014:8:31-40.

43. Blanquer-Rosselló MM, Santandreu FM, Oliver J, Roca P, Valle A. Leptin modulates mitochondrial function, dynamics and biogenesis in MCF-7 cells. J Cell Biochem. 2015:116:2039-48.

44. Bouloumie A, Marumo T, Lafontan M, Busse R. Leptin induces oxidative stress in human endothelial cells. FASEB J. 1999:13:1231-8.

45. Sezgin Alikanoglu A, Yildirim M, Suren D, Yildiz M, Kaya V, Donem Dilli U, et al. Expression of cyclooxygenase-2 and BCl-2 in breast cancer and their relationship with triple-negative disease. J BUON. 2014;19:430-4.

46. Mazhar D, Ang R, Waxman J. COX inhibitors and breast cancer. Br J Cancer. 2006:94:346-50.

47. Chacón RD, Costanzo MV. Triple-negative breast cancer. Breast Cancer Res. 2010;12(Suppl 2):S3.

48. Martinez-Outschoorn U, Sotgia F, Lisanti MP. Tumor microenvironment and metabolic synergy in breast cancers: critical importance of mitochondrial fuels and function. Semin Oncol. 2014;41:195-216.

49. Kim DH, Song NY, Kim EH, Na HK, Joe Y, Chung HT, et al. 15-deoxy- $\Delta 12,14$ prostaglandin $\mathrm{J}_{2}$ induces $\mathrm{p} 53$ expression through Nrf2-mediated upregulation of heme oxygenase- 1 in human breast cancer cells. Free Radic Res. 2014:48:1018-27.

50. Tobar N, Cáceres M, Santibáñez JF, Smith PC, Martínez J. RAC1 activity and intracellular ROS modulate the migratory potential of MCF-7 cells through a NADPH oxidase and NFkappaB-dependent mechanism. Cancer Lett. 2008; 267:125-32.

51. Xia C, Meng Q, Liu L-Z, Rojanasakul Y, Wang X-R, Jiang B-H. Reactive oxygen species regulate angiogenesis and tumor growth through vascular endothelial growth factor. Cancer Res. 2007;67:10823-30.

52. Acharya A, Das I, Chandhok D, Saha T. Redox regulation in cancer: a double-edged sword with therapeutic potential. Oxidative Med Cell Longev. 2010;3:23-34.

53. Jiang F, Zhang Y, Dusting GJ. NADPH oxidase-mediated redox signaling: roles in cellular stress response, stress tolerance, and tissue repair. Pharmacol Rev. 2011;63:218-42.

54. Schaefer KN, Geil WM, Sweredoski MJ, Moradian A, Hess S, Barton JK. Oxidation of p53 through DNA charge transport involves a network of disulfides within the DNA-binding domain. Biochemistry (Mosc). 2015;54:932-41.

55. Wang D, Chen J, Chen H, Duan Z, Xu Q, Wei M, et al. Leptin regulates proliferation and apoptosis of colorectal carcinoma through PI3K/Akt/mTOR signalling pathway. J Biosci. 2012;37:91-101.

56. Li N, Karin M. Is NF-kappaB the sensor of oxidative stress? FASEB J. 1999;13:1137-43.

57. Dirican N, Dirican A, Sen O, Aynali A, Atalay S, Bircan HA, et al. Thiol/ disulfide homeostasis: a prognostic biomarker for patients with advanced non-small cell lung cancer? Redox Rep Commun Free Radic Res. 2016;21:197-203.

58. Leary PC O, Terrile M, Bajor M, Gaj P, Hennessy BT, Mills GB, et al. Peroxiredoxin-1 protects estrogen receptor alpha from oxidative stressinduced suppression and is a protein biomarker of favorable prognosis in breast cancer. Breast Cancer Res. 2014;16:R79.
59. Schafer FQ, Buettner GR. Redox environment of the cell as viewed through the redox state of the glutathione disulfide/glutathione couple. Free Radic Biol Med. 2001;30:1191-212.

60. Esposito K, Ciotola M, Schisano B, Misso L, Giannetti G, Ceriello A, et al. Oxidative stress in the metabolic syndrome. J Endocrinol Investig. 2006;29:791-5.

61. Tehan L, Taparra K, Phelan S. Peroxiredoxin overexpression in MCF-7 breast cancer cells and regulation by cell proliferation and oxidative stress. Cancer Investig. 2013;31:374-84.

62. Ray A, Nkhata KJ, Cleary MP. Effects of leptin on human breast cancer cell lines in relationship to estrogen receptor and HER2 status. Int J Oncol. 2007; 30:1499-509.

63. Maloberti PM, Duarte AB, Orlando UD, Pasqualini ME, Solano AR, López-Otín $C$, et al. Functional interaction between acyl-CoA synthetase 4, lipooxygenases and cyclooxygenase-2 in the aggressive phenotype of breast cancer cells. PLoS One. 2010;5:e15540.

\section{Ready to submit your research? Choose BMC and benefit from:}

- fast, convenient online submission

- thorough peer review by experienced researchers in your field

- rapid publication on acceptance

- support for research data, including large and complex data types

- gold Open Access which fosters wider collaboration and increased citations

- maximum visibility for your research: over $100 \mathrm{M}$ website views per year

At BMC, research is always in progress.

Learn more biomedcentral.com/submissions 